\title{
Discordance between Surface and Cytoplasmic Expression of the Leu-4 (T3) Antigen in Thymocytes and in Blast Cells from Childhood T Lymphoblastic Malignancies
}

\author{
Michael P. Link, Stanford J. Stewart, Roger A. Warnke, and Ronald Levy \\ Departments of Pediatrics, Medicine, and Pathology, Stanford University School of Medicine, Stanford, California, \\ and Division of Hematology/Oncology, Children's Hospital at Stanford, Palo Alto, California 94304
}

\begin{abstract}
We have examined the expression of the Leu-4 (T3) antigen on the cell surface and in the cytoplasm of blast cells from 23 patients with $T$ cell acute lymphoblastic leukemia and $T$ cell lymphoblastic lymphoma. In the majority of cases (17), the Leu-4 antigen was absent from the cell surface; however, in 16 of these 17 cases, blast cells demonstrated cytoplasmic expression of Leu-4. This discordance between surface and cytoplasmic expression of Leu-4 was also found in thymocytes and appeared to be restricted to Leu-4, in that tests of other $T$ cell antigens rarely revealed discordance between surface and cytoplasmic expression. To study further the cytoplasmic determinant identified by anti-Leu- 4 in malignant $T$ lymphoblasts, immunoprecipitation studies were performed that utilized biosynthetic labeling of established $T$ cell lines derived from $T$ lymphoblastic malignancies. By one-dimensional sodium dodecyl sulfate-polyacrylamide gel electropheresis, identical Leu-4 polypeptide families were immunoprecipitated from surface Leu-4+ and surface Leu-4-/cytoplasmic Leu-4+ cell lines. Because $T$ lymphoblastic malignancies represent proliferations of immature $T$ cells, and because the cases studied demonstrated surface phenotypes corresponding to all of the proposed stages of $T$ cell ontogeny, it appears that cytoplasmic expression of Leu-4 occurs early in $T$ cell development. The reason for the failure of these immature $T$ cells to transport the Leu- 4 molecule to their surface remains to be elucidated.
\end{abstract}

\section{Introduction}

Studies of immunologic membrane markers of malignant cells from human lymphoid leukemias and lymphomas have revealed the heterogeneous nature of these diseases. The majority of these malignancies now are known to be neoplasms that originate in cells at various stages of maturation in $T$ or $B$ lineage (1-6). Analysis of cases of $T$ lineage malignancy with a series of monoclonal antibodies has provided important insights into the heterogeneity within the subset of $T$ cell lymphoproliferations (7-13). These studies of malignant cells in conjunction with studies of normal lymphocytes of $T$ cell lineage from peripheral blood, thymus, and other tissues have

Address correspondence to Dr. Link, Children's Hospital at Stanford, 520 Willow Road, Palo Alto, CA 94304.

Received for publication 30 October 1984 and in revised form 20 February 1985.

J. Clin. Invest.

(C) The American Society for Clinical Investigation, Inc.

0021-9738/85/07/0248/06 \$1.00

Volume 76, July 1985, 248-253 added considerably to our understanding of normal $T$ cell ontogeny. A model for $\mathrm{T}$ cell maturation has been proposed based upon these studies in which the stages of $\mathrm{T}$ cell maturation are characterized by profound changes in cell surface antigen expression $(7,9,10)$. According to this model, cells at the earliest stage of $T$ cell ontogeny (which express the $T 9$ and T10 antigens) acquire the thymocyte-specific antigen, Leu-6 (T6), as well as "helper" and "suppressor" antigens (Leu-3 and Leu-2 [T4, T5]) with further maturation to the "cortical thymocyte" stage. The segregation of $T$ cells into helper (Leu2-/Leu-3+) and cytotoxic/suppressor (Leu-2+/Leu-3-) populations occurs in the late stages of intrathymic maturation as cells acquire antigenic profiles which resemble the phenotypes of mature $\mathrm{T}$ cells found in the peripheral blood compartment. A feature of this model of $T$ cell ontogeny is that Leu-4 (T3), a pan- $T$ antigen found on mature $T$ cells, is not expressed until the late thymocyte stage when $T$ cell subset commitment is established.

Support for this model of $\mathrm{T}$ cell maturation derives from studies of $T$ lymphoblastic malignancies ( $T$ cell acute lymphoblastic leukemia [T-ALL] ${ }^{1}$ and $T$ cell lymphoblastic nonHodgkin's lymphoma [T-NHL]), which are presumed to arise from immature $T$ cells. The majority (although not all) of cases studied demonstrate surface antigenic profiles consistent with the proposed stages of $\mathrm{T}$ cell maturation, thus supporting the concept that malignant cells in these lymphoproliferations represent the progeny of a transformed cell frozen at one point in normal cellular differentiation. As predicted by the model, blast cells from the majority of cases of $T$ lymphoblastic malignancies do not express the Leu-4 antigen (7-13); thus, the majority of cases of T-ALL and T-NHL are presumed to arise from early and mid-thymocytes.

We have examined cases of $\mathrm{T}$ lymphoblastic malignancies for surface as well as cytoplasmic expression of $T$ cell antigens, and we have found a discordance between surface and cytoplasmic expression of the Leu-4 antigen. As in previous reports, the Leu-4 antigen is absent, or weakly expressed, on the cell surface in the majority of cases. However, in virtually all cases of T-ALL and T-NHL, intracellular Leu-4 antigen is found in blast cells even when the antigen is absent from the cell surface.

\section{Methods}

Monoclonal antibodies. Monoclonal antibodies Leu-1 (Pan-T), Leu-2a (T cytotoxic/suppressor), Leu-3a (T helper), Leu-4 (Pan-T), Leu-5 (E rosette receptor), Leu-6 (thymocyte), Leu-9 (T-ALL/NHL), Leu-12 (B

1. Abbreviations used in this paper: PAGE, polyacrylamide gel electrophoresis; T-ALL, T cell acute lymphoblastic leukemia; T-NHL, T cell lymphoblastic non-Hodgkin's lymphoma. 
cell), HLA-DR, and CALLA (common acute lymphoblastic leukemia antigen) were generously supplied by the Becton-Dickinson Monoclonal Center (Mountain View, CA). Monoclonal antibodies OKT9 (transferrin receptor) and OKT10 were purchased from Ortho Pharmaceuticals (Raritan, NJ). Monoclonal antibody B1 was purchased from Coulter Laboratories (Hialeah, FL). The methods of development of these reagents and the distribution of the antigens detected by these reagents on normal tissues and malignant cells have been reported previously (7, 12-21).

Patients and cells. Malignant cells were obtained from patients at the time of initial presentation or relapse after informed consent was obtained. Tissue analyzed included lymph nodes, pleural effusions, bone marrow, and peripheral blood. Only specimens containing $>80 \%$ malignant cells were analyzed. The diagnosis in each case was established by standard morphologic and histochemical parameters. Normal thymus glands were obtained from fresh surgical specimens.

Immunophenotyping studies were performed on cells in single-cell suspension and also in tissue section. Cell suspensions were made from leukemia and lymphoma cells which were isolated from heparinized bone marrow, peripheral blood, and malignant effusions by FicollHypaque density sedimentation. Single-cell suspensions were also made from lymphomatous masses and lymph nodes which were gently teased and passed through a stainless steel mesh. In the majority of cases, immunophenotyping studies were performed on cell suspensions when first obtained, but in some cases immunophenotype analysis was performed on cells cryopreserved by using standard techniques and stored at $-196^{\circ} \mathrm{C}$ in $10 \%$ dimethylsulfoxide and $10 \%$ fetal calf serum. There was no difference in cell surface markers when performed sequentially on fresh and frozen cells.

The cell lines 255.88 (22) (a T-T hybrid line) and HPB-ALL (23) were utilized in these studies. Characteristics of these lines have been previously described.

Immunophenotyping studies. Cell surface antigens were identified by the binding of monoclonal antibody detected by indirect immunofluorescence. One million cells were placed in plastic tubes and incubated with $1 \mu \mathrm{g}$ of purified monoclonal antibody at $4^{\circ} \mathrm{C}$ for 20 min. Cells were washed twice in the cold in phosphate-buffered saline plus $0.02 \%$ sodium azide to remove excess antibody, and incubated for $20 \mathrm{~min}$ at $4^{\circ} \mathrm{C}$ with fluorescein isothiocyanate-conjugated goat anti-mouse immunoglobulin (Tago Inc., Burlingame, CA). The cells were washed twice, fixed in $1 \%$ formaldehyde in phosphate-buffered saline, and analyzed for fluorescence staining with a fluorescenceactivated cell sorter equipped with a log amplifier (FACS IV, Becton, Dickinson Electronics Laboratory, Mountain View, CA) interfaced with a Consort 440 computer system. The intensity of fluorescence for 10,000 cells in each sample was determined and the results were displayed as a histogram by plotting the fraction of total cells versus intensity of fluorescence for each antibody. Background fluorescence was determined by incubating the cells with a nonreactive myeloma protein in place of specific antibody. The cell population from an individual patient was felt to be reactive with an antibody if $>20 \%$ of cells demonstrated specific fluorescence when compared with the background control.

Immunologic phenotyping of frozen tissue sections was performed by utilizing a biotin-avidin-horseradish peroxidase technique, as previously reported (24). Representative portions of fresh surgical biopsy specimens were snap-frozen, sectioned, and acetone-fixed before staining. The frozen sections were sequentially stained with unconjugated monoclonal antibody followed by biotinilated goat anti-mouse IgG (Tago Inc.) or horse anti-mouse IgG (Vector Laboratories, Inc., Burlingame, CA) followed by avidin-horseradish-peroxidase conjugate (Vector Laboratories). Individual cells were identified on the basis of characteristic histologic features and antigen expression. As in the cell suspension studies, isotype-matched nonreactive myeloma proteins were used as controls for background staining.

Cytocentrifuge preparations were prepared from the single-cell suspensions by utilizing a Shandon cytocentrifuge (Shandon Cytopsin 2, Shandon Southern Instruments, Inc., Sewickley, PA). Multiple samples, $\sim 150,000$ cells each, were centrifuged onto glass slides, fixed in acetone, and then stained by utilizing the biotin-avidin-horseradish peroxidase technique as described above. Immunophenotyping of tissue sections and cytocentrifuge preparations after fixation reveals intracellular as well as surface antigen expression (25-28).

Immunoprecipitation of Leu-4 antigen. HPB-ALL and 255.88 cells, $\sim 2 \times 10^{8}$, were harvested in logarithmic growth phase, washed twice in Dulbecco's phosphate-buffered saline, and resuspended in cysteine/ methionine-free RPMI-1640 medium (Selectamine kit, Gibco Laboratories, Grand Island, NY) supplemented with $10 \%$ dialyzed, heatinactivated fetal calf serum. After a $45-\mathrm{min}$ preincubation at $37^{\circ} \mathrm{C}$ in a $5 \% \mathrm{CO}_{2}$ environment, $1.0 \mathrm{mCi}$ each of $\left[{ }^{35} \mathrm{~S}\right]$ cysteine $(1,076 \mathrm{Ci} /$ $\mathrm{mmol}$ ), and $\left[{ }^{35} \mathrm{~S}\right]$ methionine $(1,064 \mathrm{Ci} / \mathrm{mmol})$ (New England Nuclear, Boston, MA) were added. Incubation of cells was continued for 120 min. Cells were harvested by centrifugation, washed twice, in Dulbecco's phosphate-buffered saline, and lysed in 0.5\% NP-40 (BDH, Gallard and Schlesinger, New York) lysis buffer containing Tris-HCl $50 \mathrm{mM}$, pH 7.4, $\mathrm{NaCl} 0.15 \mathrm{M}$, EDTA $5 \mathrm{mM}$, phenylmethylsulfonyl fluoride 2 $\mathrm{mM}$, aprotinin $0.2 \mathrm{TIU} / \mathrm{ml}$ (Sigma Chemical Co., St. Louis, MO), and iodoacetamide $25 \mathrm{mM}$ (Eastman Kodak Co., Rochester, NY) on ice. Nuclei were removed and lysates clarified by centrifugation. Cell lysates were precleared with immunoprecipitates formed in situ by the addition of an irrelevant class-matched IgG1 antibody L368 (anti- $\beta$-2-microglobulin) $10 \mu \mathrm{g}$, and goat anti-mouse IgG (EY Labs, San Mateo, CA) at $4^{\circ} \mathrm{C}$ over $6 \mathrm{~h}$ while slowly rotating. Specific immunoprecipitation, using $10 \mu \mathrm{g}$ of specific, purified, anti-Leu-4 antibody and goat antimouse IgG at equivalence, was performed in a similar fashion over $18 \mathrm{~h}$. Precipitates were collected by centrifugation and washed six times in $\mathrm{NaCl}$-EDTA-Tris buffers containing $\mathrm{NaCl} 0.15 \mathrm{M}$, EDTA 5 $\mathrm{mM}$, Tris- $\mathrm{HCl} 50 \mathrm{mM}, \mathrm{pH} 7.4, \mathrm{Na}$ azide $0.02 \%$, NP-40 decreasing from 1 to $0 \%$, and additional $\mathrm{NaCl}$ to $0.5 \mathrm{M}$ in the first four washes. One-dimensional sodium dodecyl sulfate-polyacrylamide gel electrophoresis (SDS-PAGE) of samples was carried out on 10\% acrylamide gels as described previously by Laemmli (29).

\section{Results}

10 cases of $T$ cell acute lymphoblastic leukemia and 13 cases of $T$ cell lymphoblastic lymphoma were studied for both surface and cytoplasmic antigen expression. In all cases, the diagnosis was confirmed by examination of appropriately stained tissue by utilizing standard morphologic criteria. The $T$ cell lineage of these malignancies was confirmed by the reactivity of blast cells with one or more $T$ lineage antibodies. In all 22 cases tested, blast cells were reactive with anti-Leu-9. We and others have shown previously that expression of the 40,000 mol wt antigen defined by Leu-9 (4H9) (13) or its equivalents (WT1 [30], 3A1 [31]) reliably confirms $T$ cell lineage among the childhood lymphoblastic leukemias and lymphomas.

Results of surface immunophenotyping of malignant cells in suspension are shown in Table I. As in other series of T-ALL and T-NHL, the majority (17 of 23) of cases were Leu-4 negative. In all Leu-4-negative cases, $<15 \%$ of cells expressed the Leu-4 antigen, and among the Leu-4-positive cases, expression of Leu-4 was generally weak; in only two cases was Leu- 4 expressed by $>50 \%$ of the malignant cells.

In 13 cases (NHL-9, ALL-4), cell suspensions and frozen sections were made from identical tissue allowing direct comparison of the two techniques of immunophenotyping. In 10 additional cases where frozen tissue was not available, cytocentrifuge preparations were made from the cell suspension, fixed, and then processed like tissue sections. On the one hand, results of staining of frozen tissue sections and cytocentrifuge 
Table I. Results of Surface Immunophenotyping

\begin{tabular}{|c|c|c|c|c|c|c|c|c|c|}
\hline Case & Leu-1 & Leu-2 & Leu-3 & Leu-4 & Leu-5 & Leu-6 & Leu-9 & T 9 & T 10 \\
\hline \multicolumn{10}{|l|}{ ALL } \\
\hline 1 & + & - & - & - & NT & - & + & NT & NT \\
\hline 2 & + & - & - & - & - & - & + & - & - \\
\hline 3 & + & - & - & - & - & - & + & NT & NT \\
\hline 4 & + & - & + & - & + & + & + & - & + \\
\hline 5 & + & + & + & - & + & NT & NT & NT & NT \\
\hline 6 & + & + & + & - & + & + & + & + & + \\
\hline 7 & + & - & - & + & - & - & + & + & + \\
\hline 8 & + & - & - & + & - & - & + & - & + \\
\hline 9 & + & + & - & + & - & - & + & + & + \\
\hline 10 & + & + & + & + & + & NT & + & NT & NT \\
\hline \multicolumn{10}{|l|}{ NHL } \\
\hline 11 & + & - & - & - & - & - & + & - & + \\
\hline 12 & + & - & - & - & - & NT & + & NT & NT \\
\hline 13 & + & - & - & - & - & - & + & - & + \\
\hline 14 & + & - & - & - & - & - & + & + & - \\
\hline 15 & + & - & - & - & - & + & + & NT & NT \\
\hline 16 & + & + & + & - & NT & + & + & - & + \\
\hline 17 & + & + & + & - & + & + & + & + & - \\
\hline 18 & + & + & + & - & + & + & + & - & + \\
\hline 19 & + & + & + & - & + & + & + & - & + \\
\hline 20 & + & + & + & - & + & + & + & - & + \\
\hline 21 & + & + & + & - & + & - & + & - & + \\
\hline 22 & + & - & - & + & - & + & + & NT & NT \\
\hline 23 & + & - & + & + & + & - & + & - & + \\
\hline
\end{tabular}

NT, not tested.

preparations after acetone fixation have been identical in our laboratories (Link, M. P., and R. A. Warnke, unpublished data). On the other hand, it has been reported previously that fixation of cells or tissue before immunologic staining results in demonstration of intracytoplasmic as well as surface antigens whereas staining of unfixed cells in suspension demonstrates only surface antigens (25-28). 148 tests for $T$ cell antigens were performed in the 23 cases. Excluding testing for Leu-4, there was concordance of results for 116 of 125 (93\%) antigens tested in fixed and unfixed cells (Table II). Of the nine discordant results, most reflected weak antigen expression as detected by one technique which was scored as negative by the other.

Results of testing for Leu-4 in fixed and unfixed cells demonstrated markedly discordant results. Malignant cells from 17 cases did not express Leu-4 on the cell surface, yet,

Table II. Summary of Cases Analyzed

for Surface and Cytoplasmic Antigens

\begin{tabular}{llllll}
\hline & & & & & \\
Dx & Cases & $\begin{array}{l}\text { Tissue/ } \\
\text { Cyto-prep }\end{array}$ & $\begin{array}{l}\text { Surface } \\
\text { Leu-4- }\end{array}$ & $\begin{array}{l}\text { Cytoplasmic } \\
\text { Leu-4+ }\end{array}$ & $\begin{array}{l}\text { Concordance } \\
\text { at other antigens } \\
\text { tested }\end{array}$ \\
\hline & $n$ & $n$ & $n$ & $n$ & \\
ALL & 10 & $4 / 6$ & 6 & 6 & $47 / 51$ \\
NHL & 13 & $9 / 4$ & 11 & 10 & $69 / 74$ \\
Total & 23 & $13 / 10$ & 17 & 16 & $116 / 125(93 \%)$ \\
\hline
\end{tabular}

in all but one of these cases $(94 \%)$, fixed cells were strongly reactive with anti-Leu-4. The results of one such case (case 19) are shown in Fig. 1. In an additional six cases, the blast cells expressed Leu-4 on the cell surface and testing of fixed cells from these cases also revealed strong expression of Leu4. In only one of the 23 cases studied, fixed cells were found to be Leu-4 negative (case 11). In that fixation of cells before staining allows for the detection of intracellular as well as surface antigens, anti-Leu-4 apparently reacts with an intracellular determinant in $\mathrm{T}$ lymphoblastic malignancies.

The $\mathrm{T}$ lymphoblastic malignancies are presumed to derive from thymocytes at various stages of maturation. To examine if discordance of Leu-4 expression on the cell surface and in cytoplasm is a feature of normal $T$ cell ontogeny or a feature unique to malignant cells, normal human thymocytes obtained from surgical specimens were examined for Leu-4 expression. When studied in cell suspension $\sim 35-40 \%$ of thymocytes were found to express surface Leu-4. Study of thymocytes in frozen section after fixation revealed that $>90 \%$ of thymocytes (including cortical thymocytes) are reactive with anti-Leu-4.

To study further the intracellular determinant identified by anti-Leu-4 in malignant $T$ lymphoblasts, immunoprecipitation studies were performed utilizing established $T$ cell lines derived from $\mathrm{T}$ lymphoblastic malignancies. The HPB-ALL cell line expressed the Leu-4 antigen on the cell surface, whereas the 255.88 cell line (a derivative of the Jurkat cell line) demonstrated discordant Leu- 4 expression when studied in cell suspension and in cytocentrifuge preparations after fixation. The two cell lines were biosynthetically labeled with $\left[{ }^{35} \mathrm{~S}\right]$ cysteine and $\left[{ }^{35} \mathrm{~S}\right]$ methionine; immunoprecipitation with anti-Leu-4 and analysis of the two cell lines by SDS-PAGE were then run in parallel. As demonstrated by the gel tracks in Fig. 2, biosynthetically labeled material reactive with antiLeu-4 was immunoprecipitated from both cell lines. This

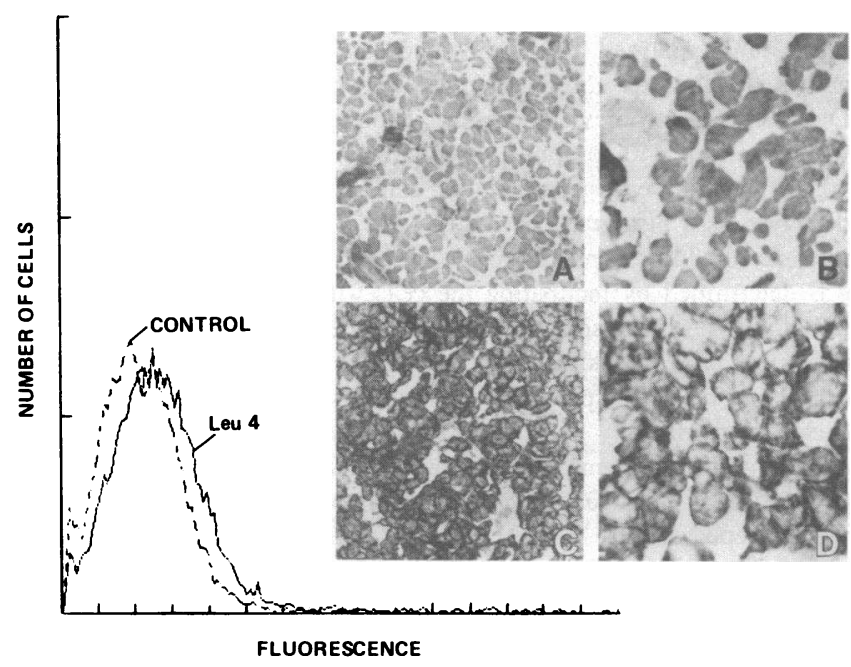

Figure 1. Comparison of cell suspension staining analyzed by FACS and tissue section staining of case 19. The FACS histogram demonstrates virtual absent reactivity with anti-Leu-4 when compared with an irrelevant isotype-matched control myeloma protein. By contrast, low- and high-power photomicrographs from immunophenotyping studies done in tissue section demonstrate strong reactivity with antiLeu-4 indicated by dark staining cells $(C$ and $D)$ compared with staining with control myeloma protein $(A$ and $B)$. 

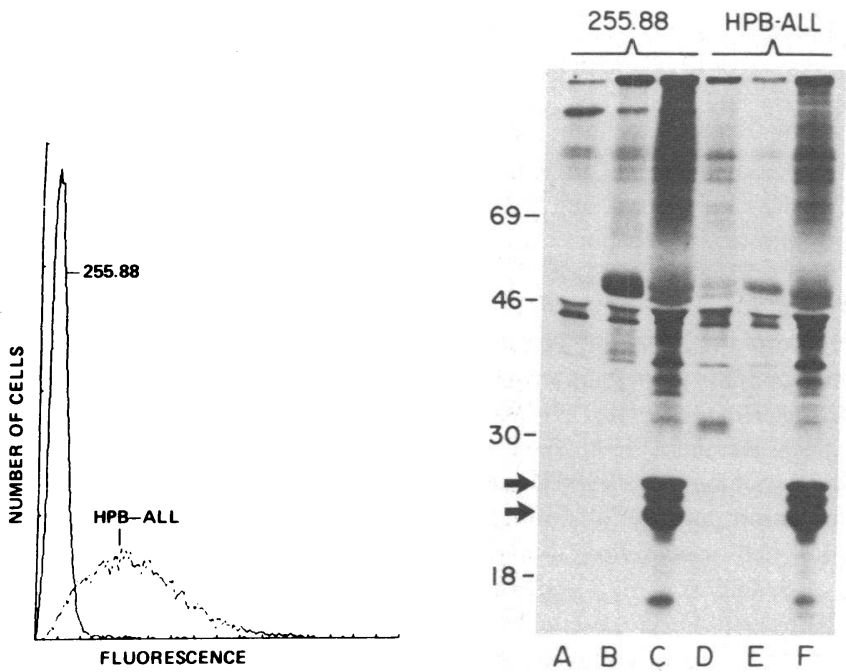

Figure 2. Immunoprecipitation of the Leu-4 antigen from cell lines HPB-ALL and 255.88. On the left, FACS histograms of cell surface staining of the two cell lines demonstrate surface Leu-4 antigen expression by HPB-ALL. The histogram for 255.88 was superimposable upon that obtained using an irrelevant isotype-matched control, confirming that this cell line is surface Leu-4 negative. On the right, SDS-PAGE analysis of Leu-2 (lanes $A$ and $D$ ), Leu-3 (lanes $B$ and $E$ ), and Leu-4 (lanes $C$ and $F$ ) specific immunoprecipitates from 255.88 (lanes $A-C$ ) and HPB-ALL (lanes D-F) compares antigen metabolically labeled with radioactive amino acids, methionine and cysteine. Arrows point to the family of molecules immunoprecipitated by anti-Leu- 4 .

material had a molecular weight of 22,000-26,000 as previously described (32). Moreover, by one-dimensional SDS-PAGE analysis, the major polypeptide families of Leu-4 immunoprecipitated from the two cell lines appeared indistinguishable. Over the 2-h labeling period, as much or more anti-Leu-4reactive material was synthesized by cell line 255.88 , which is surface Leu-4 negative.

\section{Discussion}

The Leu-4 (T3) antigen consists of a family of glycoprotein molecules of $\sim 25,000 \mathrm{~mol} w t$ on the surface of all peripheral blood $T$ cells and $30-60 \%$ of thymocytes. This antigen is not found on the surface of leukocytes outside the $T$ cell lineage. The absence of this molecule on the surface of the majority of thymocytes and the majority of cases of T-ALL and T-NHL, which are presumed to be derived from thymocytes, has led investigators to conclude that expression of Leu-4 is restricted to mature thymocytes and $T$ cells.

In this report, 23 cases of T-ALL and T-NHL have been studied for surface as well as intracellular expression of Leu4. As in other series, we found that blast cells from the majority (74\%) of cases of T-ALL and T-NHL failed to express the Leu-4 antigen on the cell surface. However, we have demonstrated a discordance between surface and cytoplasmic expression of Leu-4 in T lymphoblastic malignancies. Discordance in results of testing for Leu-4 between fixed and unfixed cells was found in 16 of 23 cases $(70 \%)$ compared to a discordance rate of only $7 \%$ for all other antigens tested. Moreover, six of the cases studied were surface Leu-4+ where no discordance could be detected. Thus, of 17 cases which were surface Leu-4 negative, $16(94 \%)$ expressed intracellular Leu 4.

One potential explanation of the discordant results of testing is cross-reactivity of the anti-Leu-4 antibody with another determinant modified by the fixation process. However, immunoprecipitation of a family of polypeptides indistinguishable from the Leu-4 antigen from the surface Leu-4-/cytoplasmic Leu $4+$ cell line 255.88 supports the concept that the determinant recognized in fixed cells from $T$ lymphoblastic malignancies is, in fact, the Leu- 4 antigen. The cytoplasmic form of the Leu-4 antigen does not appear to be a precursor molecule because the molecular weight of the polypeptide is not different from that found in cells expressing surface Leu4 (Fig. 2); nor is it different from the molecular weight previously reported in mature $T$ cells. The explanation for the apparent intracellular limitation of the Leu-4 antigen and failure of surface expression in malignant $T$ cells and thymocytes is unknown.

Discordance between surface and cytoplasmic antigen expression has been noted previously in other leukocytes, and, in some instances, the lineage specificity of certain antigens has been challenged because of these findings. For example, intracytoplasmic expression of the Leu-4 (T3) antigen has been demonstrated in normal monocytes and B chronic lymphocytic leukemia cells $(27,28)$. In our study of $T$ lymphoblastic malignancies, we examined intracellular expression of several putatively B lineage-specific antigens as well (data not shown). We did not detect intracytoplasmic expression of B lineage antigens in any of these cases. Nor did we note a consistent discrepancy between surface and cytoplasmic antigen expression for any but the Leu-4 antigen. However, the consistent discordance in Leu-4 expression in $\mathrm{T}$ lymphoblastic malignancies and discordances noted by other investigators suggest that the repertoire of antigen expression of a cell should not be inferred from studies of surface antigen expression alone.

In our study of T-ALL and T-NHL, cases representing all stages of thymocyte development were examined, and only one failed to express intracellular or cell surface Leu-4. This case (no. 11) would be classified in the earliest stage of $T$ cell development expressing only the Leu-1, Leu-9, and T10 antigens. Other cases in our study expressing the early thymocyte phenotype (cases 1-3 and 12-14) did demonstrate intracellular but not surface Leu-4. The finding that virtually all normal thymocytes and malignant $T$ cells (even those expressing the early thymocyte phenotype) express Leu-4, at least intracellularly, suggests that expression of cytoplasmic Leu-4 must occur very early in $\mathrm{T}$ cell development.

An analogous situation where a cellular antigen is detectable in the cytoplasm before its expression on the cell surface has been noted in studies of B cell ontogeny $(3,33-35)$, where cytoplasmic expression of the heavy chain of immunoglobulin occurs early in B cell maturation at the so-called "pre-B stage" before surface immunoglobulin expression. Lymphoid leukemias $(3,4)$ and lymphomas (36) with this pre-B phenotype have been identified, and these cases of pre-B ALL and NHL have been cited to support the concept that lymphoid neoplasms represent clonal expansions of cells frozen at discrete stages of lymphocyte maturation. Further studies of lymphoid neoplasms of B lineage have revealed the molecular events that occur at different stages of B cell development. Commitment to immunoglobulin synthesis has been shown to occur at the earliest stage of B cell ontogeny $(37,38)$. Studies of T cell neoplasms 
indicate that an analogous series of events occurs in $T$ cell development. Recent studies of thymocytes, of tumor cells from patients with $\mathrm{T}$ lymphoblastic leukemia and lymphoblastic lymphoma (39), and of cell lines derived from thymic leukemias (40) have demonstrated that rearrangements of the gene for the $T$ cell receptor occurs in immature cells of $T$ lineage that express the mid- and late-thymocyte phenotype, although not in cells that express the early thymocyte phenotype. Apparently, rearrangement of the $T$ cell receptor gene occurs early (if not at the earliest stage) in $T$ cell ontogeny. Our studies indicate that synthesis of the Leu- 4 antigen, a molecule which is critical to the function of the mature $T$-cell, likewise occurs in immature $T$ cells, and may precede the rearrangement of the $T$ cell receptor gene inasmuch as the Leu- 4 antigen can be found in cells expressing even the most immature thymocyte phenotype.

The pivotal role of the Leu-4 antigen in the function of the mature $T$ cell is now recognized. Recent studies have demonstrated that the $T$ cell receptor is noncovalently linked to Leu-4 (T3) on the cell surface (41-43). Moreover, experiments that utilize mutants of the Jurkat $T$ cell leukemia line (44) suggest an intimate interdependence in the surface expression of the Leu- 4 and $T$ receptor molecules; surface expression of neither of these molecules occurs without co-expression of the other. In that the Leu-4 antigen is not expressed on the cell surface until late in $T$ cell ontogeny, antigen specificity is not conferred upon the maturing $T$ cell until late in $T$ cell development. From our study, it is apparent that the Leu-4 molecule can be demonstrated intracellularly early in $T$ cell ontogeny. Because the intracellular Leu-4 antigen is apparently similar to the surface-expressed polypeptide, it is not clear why expression is restricted to the cytoplasm. It is possible that synthesis of the Leu- 4 antigen precedes the synthesis of at least part of the $T$ cell receptor heterodimer in $T$ cell ontogeny. As in the pre-B cell where the immunoglobulin heavy chain is restricted to the cytoplasm until light chain synthesis occurs (45), the surface Leu-4-/cytoplasmic Leu-4+ T cell leukemias may represent an early stage of $T$ cell development where the Leu-4 portion of the $T$ cell receptor complex is restricted to the cytoplasm before synthesis of the $T$ cell receptor heterodimer. Studies are now underway to test this hypothesis.

\section{Acknowledgments}

We gratefully acknowledge the technical assistance of Catherine Carswell and Jane Bindl. We thank Delores Dewey and Luella Walter for their excellent secretarial assistance during the preparation of this manuscript.

This work was supported in part by grants CA-21223, CA-32739, and CA-34233 from the National Institutes of Health. Dr. Stewart is a recipient of grant PRTF3 from the American Cancer Society.

\section{References}

1. Greaves, M. F. 1981. Analysis of the clinical and biological significance of lymphoid phenotypes in acute leukemia. Cancer Res. 41:4752-4766.

2. Foon, K. A., R. W. Schroff, and R. P. Gale. 1982. Surface markers on leukemia and lymphoma cells: recent advances. Blood. 60: $1-19$.

3. Vogler, L. B., W. M. Crist, D. E. Bockman, E. R. Pearl, A. R. Lawton, and M. D. Cooper. 1978. Pre-B-cell leukemia. A new phenotype of childhood lymphoblastic leukemia. N. Engl. J. Med. 298:872-878.

4. Vogler, L. B., W. M. Crist, A. M. Sarrif, D. J. Pullen, A. A.
Bartolucci, J. M. Falletta, B. Dowell, G. B. Humphrey, R. Blackstock, J. van Eys, R. S. Metzgar, and M. D. Cooper. 1981. An analysis of clinical and laboratory features of acute lymphocytic leukemias with emphasis on 35 children with pre-B leukemia. Blood. 58:135-140.

5. Sallan, S. E., J. Ritz, J. Pesando, R. Gelber, C. O'Brien, S. Hitchcock, F. Coral, and S. F. Schlossman. 1980. Cell surface antigens: prognostic implications in childhood acute lymphoblastic leukemia. Blood. 55:395-402.

6. Greaves, M. F., G. Janossy, J. Peto, and H. Kay. 1981. Immunologically defined subclasses of acute lymphoblastic leukaemia in children: their relationship to presentation features and prognosis. Br. J. Haematol. 48:179-197.

7. Reinherz, E. L., P. C. Kung, G. Goldstein, R. H. Levey, and S. F. Schlossman. 1980. Discrete stages of human intrathymic differentiation: analysis of normal thymocytes and leukemic lymphoblasts of T-cell lineage. Proc. Natl. Acad. Sci. USA. 77:1588-1592.

8. Greaves, M. F., J. Rao, G. Hariri, W. Verbi, D. Catovsky, P. Kung, and G. Goldstein. 1981. Phenotypic heterogeneity and cellular origins of T cell malignancies. Leuk. Res. 5:281-299.

9. Reinherz, E. L., and S. F. Schlossman. 1981. Derivation of human T-cell leukemias. Cancer Res. 41:4767-4770.

10. Bernard, A., L. Boumsell, E. L. Reinherz, L. M. Nadler, J. Ritz, H. Coppin, Y. Richard, F. Valensi, J. Dausset, G. Flandrin, J. Lemerle, and S. F. Schlossman. 1981. Cell surface characterization of malignant $\mathrm{T}$ cells from lymphoblastic lymphoma using monoclonal antibodies: evidence for phenotypic differences between malignant $T$ cells from patients with acute lymphoblastic leukemia and lymphoblastic lymphoma. Blood. 57:1105-1110.

11. Roper, M., W. M. Crist, R. Metzgar, A. H. Ragab, S. Smith, K. Starling, J. Pullen, B. Leventhal, A. A. Bartolucci, and M. D. Cooper. 1983. Monoclonal antibody characterization of surface antigens in childhood T-cell lymphoid malignancies. Blood. 61:830-837.

12. Koziner, B., D. Gebhard, T. Denny, S. McKenzie, B. D. Clarkson, D. A. Miller, and R. L. Evans. 1982. Analysis of T-cell differentiation antigens in acute lymphatic leukemia using monoclonal antibodies. Blood. 60:752-757.

13. Link, M., R. Warnke, J. Finlay, M. Amylon, R. Miller, J. Dilley, and R. Levy. 1983. A single monoclonal antibody identifies Tcell lineage of childhood lymphoid malignancies. Blood. 62:722-728.

14. Engleman, E. G., R. Warnke, R. I. Fox, J. Dilley, C. J. Benike, and R. Levy. 1981. Studies of a human $T$ lymphocyte antigen recognized by a monoclonal antibody. Proc. Natl. Acad. Sci. USA. 78: 1791-1795.

15. Evans, R., D. Wall, C. Platsoucas, F. Siegal, S. Fikrig, C. Testa, and R. Good. 1981. Thymus-dependent membrane antigens in man: inhibition of cell-mediated lympholysis by monoclonal antibodies to $\mathrm{Th}_{2}$ antigen. Proc. Natl. Acad. Sci. USA. 78:544-548.

16. Ledbetter, J. A., R. L. Evans, M. Lipinski, C. CunninghamRundles, R. A. Good, and L. A. Herzenberg. 1981. Evolutionary conservation of surface molecules that distinguish $\mathrm{T}$ lymphocyte helper/ inducer and cytotoxic/suppressor subpopulations in mouse and man. J. Exp. Med. 153:310-323.

17. Friedrich, W., R. J. O'Reilly, B. Koziner, D. F. Gebhard, R. A. Good, and R. L. Evans. 1982. T-lymphocyte reconstitution in recipients of bone marrow transplants with and without GVHD: Imbalances of T-cell subpopulations having unique regulatory and cognitive functions. Blood. 59:696-701.

18. Lampson, L., and R. Levy. 1980. Two forms of Ia molecules on a human B cell line. J. Immunol. 125:293-299.

19. Pesando, J., J. Ritz, H. Lazarus, S. Costello, S. Sallan, and S. Schlossman. 1979. Leukemia associated antigens in ALL. Blood. 54: $1240-1248$.

20. Meeker, T. C., R. A. Miller, M. P. Link, J. Bindl, R. Warnke, and R. Levy. 1984. A unique human $B$ lymphocyte antigen defined by a monoclonal antibody. Hybridoma. 3:305-320.

21. Stashenko, P., L. M. Nadler, R. Hardy, and S. F. Schlossman. 1980. Characterization of a human B-lymphocyte-specific antigen. $J$. Immunol. 125:1678-1685. 
22. Foung, S. K. H., D. T. Sasaki, F. C. Grumet, and E. G. Engleman. 1982. Production of functional human T-T hybridomas in selection medium lacking aminopterin and thymidine. Proc. Natl. Acad. Sci. USA. 79:7484-7488.

23. Minowada, J., T. Tsubota, S. Nakazawa, M. Greaves, G. Janossy, H. Koshiba, I. Kubonishi, T. Han, D. Higby, A. Freeman, and L. Sinks. 1978. Cell surface markers of human leukemia-lymphoma cell lines: analysis of the marker expression on fresh leukemia cells from 527 patients. In Advances in Comparative Leukemia Research 1977. P. Bentvelzen, J. Hilers, and D. S. Yohn, editors. Elsevier/North Holland, New York. 363-366.

24. Wood, G., and R. Warnke. 1981. Suppression of endogenous avidin-binding activity in tissues and its relevance to biotin-avidin detection systems. J. Histochem. Cytochem. 29:1196-1204.

25. Taylor, C. R. 1978. Immunoperoxidase Techniques. Arch. Pathol. Lab. Med. 102:113-121.

26. Mason, D. Y., C. Farrell, and C. R. Taylor. 1975. The detection of intracellular antigens in human leucocytes by immunoperoxidase staining. Br. J. Haematol. 31:361-370.

27. Morgan, A. C., R. Schroff, J. Ortaldo, and R. B. Herberman. 1984. Occult leukocyte antigens in human NK and other lymphoid populations. Fed. Proc. 43:1805.

28. Schroff, R. W., C. D. Bucana, R. A. Klein, M. M. Farrell, and A. C. Morgan. 1984. Detection of intracytoplasmic antigens by flow cytometry. J. Immunol. Methods. 70:167-177.

29. Laemmli, U. K. 1970. Cleavage of structural proteins during the assembly of the head of bacterophage T4. Nature (Lond.). 227: 680-685.

30. Vodinelich, L., W. Tax, Y. Bai, S. Pegram, P. Capel, and M. F. Greaves. 1983. A monoclonal antibody (WT1) for detecting leukemias of T-cell precursors (T-ALL). Blood. 62:1108-1113.

31. Haynes, B. F., R. S. Metzgar, J. D. Minna, and P. A. Bunn. 1981. Phenotypic characterization of cutaneous T-cell lymphoma. Use of monoclonal antibodies to compare with other malignant T cells. $N$. Engl. J. Med. 304:1319-1323.

32. Bergman, Y., S. J. Stewart, S. Levy, and R. Levy. 1983. Biosynthesis, glycosylation, and in vitro translation of the human $\mathrm{T}$ cell antigen Leu 4. J. Immunol. 131:1876-1881.

33. Nadler, L. M., K. C. Anderson, G. Marti, M. Bates, E. Park, J. F. Daley, and S. F. Schlossman. 1983. B4, a human B lymphocyteassociated antigen expressed on normal, mitogen-activated, and malignant B lymphocytes. J. Immunol. 131:244-250.

34. Anderson, K. C., M. P. Bates, B. L. Slaughenhoupt, G. S. Pinkus, S. F. Schlossman, and L. M. Nadler. 1984. Expression of human B cell-associated antigens on leukemias and lymphomas: a model of human B cell differentiation. Blood. 63:1424-1433.
35. Nadler, L. M., S. J. Korsmeyer, K. C. Anderson, A. W. Boyd, B. Slaughenhoupt, E. Park, J. Jensen, F. Coral, R. J. Mayer, S. E. Sallan, J. Ritz, and S. F. Schlossman. 1984. B cell origin of non-T cell acute lymphoblastic leukemia. A model for discrete stages of neoplastic and normal pre-B cell differentiation. J. Clin. Invest. 74:332-340.

36. Link, M. P., M. Roper, R. F. Dorfman, W. M. Crist, M. D. Cooper, and R. Levy. 1983. Cutaneous lymphoblastic lymphoma with pre-B markers. Blood. 61:838-841.

37. Korsmeyer, S. J., P. A. Hieter, J. R. Ravetch, D. G. Poplack, T. A. Waldmann, and P. Leder. 1981. Developmental hierarchy of immunoglobulin gene rearrangements in human leukemic pre-B-cells. Proc. Natl. Acad. Sci. USA. 78:7096-7100.

38. Korsmeyer, S. J., A. Arnold, A. Bakhshi, J. V. Ravetch, U. Siebenlist, P. A. Hieter, S. O. Sharrow, T. W. LeBien, J. H. Kersey, D. G. Poplack, P. Leder, and T. A. Waldmann. 1983. Immunoglobulin rearrangement and cell surface antigen expression in acute lymphocytic leukemias of $\mathrm{T}$ cell and B cell precursor origins. J. Clin. Invest. 71: 301-313.

39. Royer H. D., O. Acuto, M. Fabbi, R. Tizard, K. Ramachandran, J. E. Smart, and E. L. Reinherz. 1984. Genes encoding the Ti B subunit of the antigen/MHC receptor undergo rearrangement during intrathymic ontogeny prior to surface T3-Ti expression. Cell. 39:261266.

40. Toyonaga, B., Y. Yanagi, N. Suciu-Foca, M. Minden, and T. W. Mak. 1984. Rearrangements of T-cell receptor gene YT35 in human DNA from thymic leukaemia T-cell lines and functional Tcell clones. Nature (Lond.). 311:385-387.

41. Acuto, O., R. E. Hussey, K. A. Fitzgerald, J. P. Protentis, S. C. Meuer, S. F. Schlossman, and E. L. Reinherz. 1983. The human $T$ cell receptor: appearance in ontogeny and biochemical relationship of alpha and beta subunits on IL-2 dependent clones and $T$ cell tumors. Cell. 34:717-726.

42. Reinherz, E. L., S. C. Meuer, and S. F. Schlossman. 1983. The human $\mathrm{T}$ cell receptor: analysis with cytotoxic $\mathrm{T}$ cell clones. Immunolog. Rev. 74:83-112.

43. Reinherz, E. L., S. Meuer, K. Fitzgerald, R. Hussey, H. Levine, and S. Schlossman. 1982. Antigen recognition by human T-lymphocytes is linked to surface expression of the $\mathrm{T}_{3}$ molecular complex. Cell. 30: 735-743.

44. Weiss, A., and J. D. Stobo. 1984. Requirement for the coexpression of $T 3$ and the $T$ cell antigen receptor on a malignant human T cell line. J. Exp. Med. 160:1284-1299.

45. Siden, E., F. Alt, L. Shinefeld, V. Sato, and D. Baltimore. 1981. Synthesis of immunoglobulin mu chain gene products precedes synthesis of light chains during B-lymphocyte development. Proc. Natl. Acad. Sci. USA. 78:1823-1827. 